\title{
The Right to Strike: Concerted Activity Under the Taft-Hartley Act
}

\author{
John Paul Jennings*
}

\section{INTRODUCTION}

$\mathrm{T}^{\mathrm{m}}$ HE WAGNER ACT ${ }^{1}$ was adopted in 1935 in order to foster and protect collective bargaining. The National Labor Relations Board in effectuation of that policy gave strong support to the efforts of employees to form their unions and to bargain collectively with their employers. The Board was bitterly attacked because it performed its duty under this law without compromise and perhaps, in retrospect, without regard to the practical, political effects of such devoted enforcement. The law was passed and the Board enforced the law in the firm belief in the basic theory of that lawthat industrial strife would be greatly lessened and perhaps eliminated if strong employers were required to set the wages, hours and working conditions of their employees by bargaining collectively with strong, independent labor organizations representing their employees. When the two met as equals, this theory ran, the very equality of their power would force a fair agreement. The employer fearing a loss if his employees struck for lack of an acceptable agreement would compromise. The union, likewise, would compromise rather than strike, fearing a loss of wages and even a possible loss of their jobs by the employees if their strike should be lost. Thus, the stage was set for the reasonable employer and the reasonable union to sit down across the bargaining table and to settle their problems in a sweetly reasonable way.

In a perfect world peopled only with the fictional reasonable man, the collective bargaining principle undoubtedly would work that way in all cases. In the great majority of instances, even with the normal unreasonable man, it has worked very well indeed. But, inevitably, for one reason or another, agreement was not reached and strikes were called. The reasons for the breakdown of negotiations are not the concern of this paper. At one extreme is the bitter, anti-union employer who has never accepted collective bargaining and who hopes each time he bargains that he may be able to break the union. At the other end is the radical union whose leaders have never accepted capitalism and who see in each bargaining conference the opportunity to demonstrate irreconcilable conflict between employer and employee and possibly to move closer to the ultimate aim of workerownership of all industry. Either of these extremists for irrational reasons may force a strike. There may be other irrational causes. Generally, however, the strike results from perfectly understandable and rational causes; for example, inability to agree on a wage which both parties consider fair or to agree on premium pay for overtime or on the granting of certain con-

* Member, San Francisco Bar.

${ }^{149}$ STAT. 449 (1935), 29 U.S.C. $\S 151$ et seq. (1946). 
ditions of employment, or a pension plan or similar betterment in the conditions of employees.

In these instances a breakdown of the collective bargaining process results in the two parties seeking to resolve by force what should be resolved by discussion. In the end, either the disagreenent must be settled by discussion or one of the combatants will be defeated; the employer's business will be destroyed or the union broken. In the great majority of instances, strikes are settled, and settled by agreement. One or the other weakens, backs down and accepts the formerly unacceptable terms.

This phenomenon has caused much brow wrinkling among our legislators and our labor specialists. They have been concerned also with strikes called for reasons which are generally agreed to be improper and with methods of conducting strikes or strike tactics which seem to them improper.

The Taft-Hartley Act ${ }^{2}$ makes no effort to deal directly with strikes which occur for rational reasons, except in the cooling-off procedure provided in the case of strikes which affect the national welfare. But the Act seeks to eliminate entirely strikes for certain purposes by forbidding them in Section 8(b) (4). The prohibitions of this section are directed at certain methods of conducting a strike (e.g., secondary boycott) as well as against particular purposes for striking believed undesirable. Strikes resulting from economic disagreement remain yet to be dealt with. As will appear hereinafter, some of the prohibitions of the Taft-Hartley Act discourage all strikes by increasing the risk to the strikers, but this result is an indirect and not a direct result of the law.

When the Taft-Hartley Act was first passed, it was bitterly attacked by employee organizations as a slave-labor law. However, there was, and perhaps still is, a tendency on the part of employers and their representatives to urge that the Taft-Hartley law does not limit labor's right to strike in any important particular. Labor organizations and their representatives have urged that there are constitutional objections which invalidate many of the prohibitions in Section 8(b) (4) which restrict labor in the exercise of its concerted activities. The writer of this paper is of the opinion that the Taft-Hartley Act does effectively and constitutionally limit the exercise of the right to strike $m$ a good many particulars. The wisdom or unwisdom of the Act will not be discussed herem. That is a matter which the individual reader must determine for himself.

Initially, it should be noted that the Taft-Hartley Act, in principle, represents a reorientation of our labor policy away from encouragenent of collective bargaiming, and away from encouraging formation of employee organizations. The Taft-Hartley Act purports to favor collective bargaining, while at the same time making the organization of employee unions more difficult and seeking to guarantee and protect the right to "refrain from" bargaining collectively. To the extent that organization of unions is hampered, the Taft-Hartley law represents a reversal of the prior policy to encourage formation of employee organizations.

261 StaT. 136 (1947), 29 U.S.C. \$§ 141 et seq. (Supp. 1951). 
Before considering the main problem it will be helpful to define our terms. Basically, a strike is a concerted refusal by employees to work for their employer. With the passage of time, however, the word "strike" has come to have a broader meaning, and it is often used indiscriminately to refer to any and all concerted activity of a labor orgamzation which is intended to bring economic pressure to bear on an employer. There may be a strike, a slow-down, a refusal to handle non-union goods; or there may be an organizational picket, the unfair list or a boycott. All are familiar weapons in the economic conflict, and unless otherwise limited, "strike" herein will generally refer to any blow struck at the employer by a labor organization regardless of the method used.

\section{THE RIGHT TO STRIKE}

Labor organizations have come a long way simce the time when it was seriously urged, and occasionally decided by some courts, ${ }^{3}$ that a strike, regardless of its objective, was necessarily an unlawful conspiracy intended to injure the employer in his business. Undoubtedly, there was a common law right to strike and the courts would protect and would refuse to enjoin strikes for objectives believed by the court to be legitimate. Chief Justice Taft stated the general principle in $1921:^{4}$

Union was essential to give laborers opportunity to deal on equality with their employer. They united to exert influence upon hin and to leave him in a body in order by this inconvenience to induce him to make better terms with them. They were withholding their labor of economic value to make him pay what they thought it was worth. The right to combine for such a lawful purpose has in many years not been denied by any court. The strike became a lawful instrument in a lawful econonic struggle or competition between eniployer and employees as to the share or division between them of the joint product of labor and capital.

Recently it was urged, unsuccessfully, that there was a constitutional right to strike, so that a strike could not lawfully be prohibited." Certainly an individual working man cannot be compelled to work against his will, and so long as workmen may constitutionally quit individually, they may leave their work in a body. However, employees who strike do not quit but merely cease their work and not their employment. They claim the right to the jobs they have left and seek by the temporary withdrawal of their labor to inprove the conditions of their expected future employment. The Taft-Hartley Act, ${ }^{6}$ as did the Wagner Act, expressly provides that strikers are employees, so that in contemplation of the federal law, employees who cease work in concert do not cease to be employees and are not actually quitting their employment. It would seem clear that although there is a right to quit work in concert, there is not necessarily any constitutional

Journeymen Cordwainers of New York (People v. Melvin), 2 Wheel. Crim. C. 262

4 Amer. Foundries v. Tri-City Council, 257 U.S. 184, 209 (1921).

5 Auto Workers v. Wis. Board, 336 U.S. 245 (1949).

661 STAT. 137 (1947), 29 U.S.C. § 152(3) (Supp.1951). 
right to go further; for example, to picket or bring other economic pressure to bear on the employer in order to force a change in working conditions.

The United States Supreme Court expressed the view over 20 years ago that there was no absolute right to strike. ${ }^{7}$ In 1949, the Supreme Court expressly held that the right to strike may be regulated. ${ }^{8}$ In that case the union had called a series of temporary work stoppages designed to force the employer to yield to the union's bargaining demands. Wisconsin found this to be an unfair labor practice and ordered the umon to cease and desist. The Supreme Court held that Wisconsin had power to forbid this concerted activity which was neither constitutionally protected nor protected by the provisions of the Taft-Hartley Act, which are hereinafter considered.

As the court points out, the right to strike may be controlled in the public interest, as indeed may any right, including the right of free speech.

Although not constitutionally protected, the right to strike, in addition to its common law protection, has been given statutory protection since the Norris-LaGuardia Act of March, 1932. That law, as will be remembered, was passed in order to curb the tendency of federal courts to conclude that strikes were called for illegal objectives and might, therefore, be enjoined, or to issue temporary injunctions or restrainimg orders which hampered strikes which were clearly for legitimate objectives. In Section 2 of that law Congress declared the public policy of the United States:

... it is necessary that he [the individual, unorganized worker] have full freedom of association, self organization and designation of representatives of his own choosing, to negotiate the terms and conditions of his employment, and that he shall be free from the interference, restraint or coercion of employers of labor, or their agents, in a designation of such representatives or in self organization or in other concerted activities for the purpose of collective bargaining or other mutual aid or protection. ${ }^{10}$

In the Railway Labor Act of $1926^{11}$ the right to orgamize and bargain collectively was protected but there was no legislative protection of the right to strike- to engage in concerted activities. Nor was such protection afforded by the amended Railway Labor Act of $1934 .{ }^{12}$ But in Section 7 (a) of the National Industrial Recovery Act enacted in 1933 Congress provided that employees should have not only the right to organize and bargain collectively, but that they were to be "free from the interference, restraint or coercion of employers ... in self-orgamization or in other concerted activities for the purpose of collective bargaining or other nutual aid or protection."13

Joint Resolution 44 of June 19, 1934, created a National Labor Relations Board to carry out the enforcement of this section. This resolution,

\footnotetext{
7 Dorchy v. Kansas, 264 U.S. 286 (1924).

8 Auto Workers v. Wis. Board, supra note 5.

947 STAT. 70 (1932), 29 U.S.C. §§ 101-115 (1946).

10 Emphasis added.

1144 STAT. 577 (1926), 45 U.S.C. $\$ \$ 151$ et seq. (1946).

1248 STAT. 1186 (1934), 45 U.S.C. $\$ \$ 151$ et seq. (1946).

1348 STAT. 195 (1933), 45 U.S.C. \& 151a (1946). (Emphasis added.)
} 
expiring in June 1935, created the original National Labor Relations Board which was transferred over to full statutory existence by the Wagner Act of July 7, 1935. Section 7 of the Wagner Act contained similar language to that found in Section 7(a) and expressly forbade any interference, restraint or coercion by employers of their employees in the exercise of the right guaranteed in Section 7 "to engage in concerted activities for the purpose of collective bargaining or other mutual aid and protection."1s Nothing in the law purported to limit the right to strike, but in any event, Section 13 of the Wagner Act expressly provided that "nothing in this Act shall be construed so as to interfere with or impede or diminish in any way the right to strike." This latter language was taken, substantially verbatim, from Joint Resolution 44 referred to above.

It should be clear, therefore, that it was definitely intended as a matter of federal policy not ouly that employees should have the right to strike, but that they should be protected in the exercise of that right. This was an extremely important addition to our law but its significance was largely overlooked by Congress in its reports at the time. Perhaps Congress did not intend the language to be taken literally because, taken at face value, it protected any strike activity and forbade any employer retaliation against strikers regardless of the extremes to which they might go in their strikes.

Congress did not stop at protecting the right to strike. In Section 2(3) of the Wagner Act, it defined employees to include those whose work had ceased as a consequence of, or in connection with, any current labor dispute, or because of any unfair labor practice.

Strikers, therefore, remained employees despite their strike; indeed, they would remain employees despite the effort of employers to discharge them unlawfully because of their strike or other legitimate union activities. The argument that the law was invalid in depriving the employer of his right to terminate the employer-employee relationship was summarily disposed of by the Supreme Court in holding uulawful an employer's discrimination in the reinstatement of strikers following their application after termination of their strike..$^{15}$

The law, therefore, provided that employees might strike, that they remained employees despite their strike, and that they were entitled to protection in their striking and were to be free from discrimination by their enployer because of the fact that they did strike.

\footnotetext{
14 Emphasis added.

15 "The respondent insists that the relation of employer and employee ceased at the inception of the strike. The plain meaning of the Act is that if men strike in connection with a current labor dispute their action is not to be construed as a renunciation of the employment relation and they remain employees for the remedial purposes specified in the Act . . . ." Labor Board v. Mackay Co., 304 U.S. 333, 347 (1938).

Of course, the employer was not powerless to act, as the Court stated further: "Nor was it an unfair labor practice to replace the striking employees with others in an effort to carry on the business. ... The assurance by respondent to those who accepted employment during the strike that if they so desired their places might be permanent was not an unfair labor practice nor was it such to reinstate only so many of the strikers as there were vacant places to be filled. But the claim put forward is that the unfair labor practice indulged by the respondent was discrimination in reinstating striking employees by keeping out certain of them for the sole reason that they had been active in the union." Id. at 345-346.
} 


\section{UNLAWFUL STRIKE ACTIVITY}

As noted, the law, at least on the surface, places no limitations whatsoever upon the right to strike. Initially, the Board appeared to take the view that all concerted activities were protected by the law but that the Board in its discretion could decide that reinstatement with back pay to employees who had engaged in conduct deemed improper by the Board would be withheld in order to effectuate the policies of the law. The problem was presented to the Board in somewhat aggravated form in the case of a sit-down strike, and in the matter of Electric Boat Company the Board stated the policy which it was to follow: ${ }^{16}$

It may be noted in the first place that the action of the strikers was undertaken in protest against an unfair labor practice of the respondent. Laying aside this fact, however, we shall consider whether the strikers' conduct would in any circumstances warrant refusal of relief. We may assume that the strikers were guilty of violation of local law when they engaged in a sit-down strike on February 23. However, the local authorities, whose responsibility it is to enforce that law, failed to take a serious view of the crime, as the penalty imposed attests. As stated above, no injury to person or property resulted from the strikers' conduct. We are, therefore, in agreement with the view of its seriousnss taken by the local authorities. In such a case we see no reason to inflict a further and much more drastic penalty for violation of the Connecticut statute.

It is true that the Board, in its discretion, has withheld orders for reinstatement of strikers because of crimes committed during the course of strikes. But in each case the crime has been a more serious offense, amounting to a felony rather than a misdemeanor as here, and involving such conduct as shooting or dynamiting. In such situations, recognizing that restoration of the working relationship would not only not produce harmony, but might also involve actual danger to the employer and his representatives, we have taken the offense into account and withheld the order. There is nothing in the present case which would justify such an exercise of discretion.

The United States Supreme Court took a somewhat different view of the matter, holding that the Board had no power to direct the reinstatement of sit-down strikers or even of strikers who actually were not in the plant but who "aided and abetted" the sit-down strikers in their unlawful seizure of the employer's premises. ${ }^{17}$

167 N.L.R.B. 572, 593 (1938).

1T "But the Board, in exercising its authority under Section 10(c) to reinstate 'employees," insists that here the status of the employees was continued, despite discharge for unlawful conduct, by virtue of the definition of the term 'employees' in Section 2(3) . . . . We think that the argument misconstrues the statute. We are unable to conclude that Congress intended to compel employers to retain persons in their employ regardless of their unlawful conduct, to invest those who go on strike with an immunity froun discharge for acts of trespass or violence against the employer's property, which they would not have enjoyed had they remained at work .... We think that the true purpose of Congress is reasonably clear. Congress was intent upon the protection of the right of employees to self-organization and to the selection of representatives of their own choosing for collective bargaining without restraint or coercion ....

"... Congress also recognized the right to strike,- that the employees could lawfully cease work at their own vohtion because of the failure of the employer to meet their demands .... 
This decision and the Sands Manufacturing decision, ${ }^{18}$ upholding the discharge of employees for striking in violation of their contract, created a variety of problems. The right to engage in concerted activities was limited by the qualification that the concerted activities must be lawful and it was, therefore, necessary for the Board to determine which concerted activities were lawful and which were not. The courts have not been altogether satisfied with the manner in which the Board has resolved this problem. The Supreme Court in Auto Workers v. Wisc. Board rather pointedly underlined the conflict. ${ }^{19}$ This decision (and the language of the Court in the decision) is extremely important in the consideration of the present problem, as well as in considering the extent to which federal law protects the right to engage in concerted activities. In upholding the Wisconsin finding that intermittent work stoppages could constitutionally be prohibited as unfair labor practices and in refuting the argument made by the union (and by the Board as amicus curiae) that the work stoppages were protected activity under federal law, the Court analyzed the lawfulness of concerted activity under federal law at some length. The Court expressed agreement with circuit court decisions setting aside NLRB orders and inferentially disapproved NLRB decisions upholding various types of concerted activity as lawful and protected.

But this recognition of 'the right to strike' plainly contemplates a lawful strike,--the exercise of the unquestioned right to quit work.

"Here the strike was illegal in its inception and prosecution .... It was not a mere quitting of work and statement of grievances in the exercise of pressure recognized as lawful. It was an illegal seizure of the buildings in order to prevent their use by the employer in a lawful manner and thus by acts of force and violence to compel the employer to submit. When the employees resorted to that sort of compulsion they took a position outside the protection of the statute and accepted the risk of the termination of their enployment upon grounds aside from the exercise of the legal rights which the statute was designed to conserve." Labor Board v. Fansteel Corp., 306 U.S. 240, 255, 256 (1939).

18 Labor Board v. Sands Mfg. Co., 306 U.S. 332 (1939).

19 "Because the acts forbidden by the Wisconsin judgment are concerted activities and had a purpose to assist labor organizations in collective bargaining, it is said to follow that they are federally authorized and thereby immunized from state control." Supra note 5 at 255 .

“... If we were to read Sec. 13 as we are urged to do, to nuake the strike an absolute right and the definition to extend the right to all other variations of the strike, the effect would be to legalize beyond the power of any state or federal authorities to control not only the intermittent stoppages such as we have here but also the slowdown and perhaps the sit down strike as well. Cf. Allen-Bradley Local v. Wisconsin Employment Relations Board, 315 U.S. 740, 751. And this is not all; the management also would be disabled from any kind of self-help to cope with these coercive tactics of the umion except to submit to its undeclared demands. To dismiss or discipline employees for exercising a rigbt given them under the Act or to interfere with them or the union in pursuing it is made an unfair labor practice and if the rights here asserted are rights conferred by the Labor Management Relations Act, it is hard to see how the management can take any steps to resist or combat them without incurring the sanctions of the Act. It is certain that such a result would be inconsistent with the whole purpose disclosed by the Labor Management Relations Act. Nor do we think such is the result of any fair interpretation of the text of the Act.

"We think that this recurrent or intermittent unannounced stoppage of work to win unstated ends was neither forbidden by federal statute nor was it legalized and approved thereby." Id. at 264. Cf. Jefferson Standard Broadcasting Co., 94 N.L.R.B. No. 227 (1951), holding an enployer could lawfully fire striking employees who distributed leaflets disparaging the quality of the employer's T.V. programs. "These tactics in the circumstances of this case are hardly less indefensible than acts of physical sabotage." 
The Board has consistently held that employees who strike in violation of their contract are subject to discharge for their unlawful conduct. ${ }^{20}$ It has further held that employees who strike in order to force an employer to violate the law may be discharged for that activity; for example, those who strike to compel an employer to grant a wage increase in violation of the War Labor Disputes Act, ${ }^{2 \mathrm{x}}$ or strike to compel an employer to bargain with the striking union despite the recent certification of another union with which the employer is required by law to bargain, ${ }^{22}$ or strike to compel the employer to agree to an unlawful union security contract. ${ }^{23}$

The Board is faced with a difficult problem in passing upon cases where it is urged that employees were discharged because of unlawful concerted activities. If the employer proves that the employee has engaged in unlawful concerted activity, may the Board go behind the statement that the man was discharged for such unlawful activity? May the Board say that the employer could have discharged him for that activity, but that in fact the discharge was for lawful activity which was protected by the Act? The problem is not quite as simple as it appears to be upon the surface. Many employees commit infractions for which they could be discharged, but for which they are not discharged. In many cases the Board after reviewing all of the circumstances has reached the conclusion that an employee who committed an infraction was not discharged for that infraction but because of legitimate union activity. The Board has directed reemployment with back pay and these orders have been upheld by the courts. It can be argued that there is no reason why the Board should not have the same power to determine the similar issue in the case of unlawful strike activities.

On the other hand, the employer may urge that so far as the courts are concerned he is given the right to discharge men for such unlawful concerted activities and that he is, in effect, deprived of that right if he must satisfy the Board in every instance, not only that the man did commit the offense, but also that he was discharged for the commission of that offense. The problem, of course, is singularly acute in those cases where a strike settlement is reached and after the men return to work the employer discharges or refuses to reemploy those who, according to his investigation, have engaged in unlawful activity. In such cases, ${ }^{24}$ the Board may conclude that the employer has condoned the unlawful activity by the reemployment and that what he is really doing is singling out for discharge employees who were particularly active in the union's conduct of the strike; that is, that his primary motive is not to remove from his employ those who are objectionable because of their unlawful activity, but to remove from his employ those who are objectionable because of their outstanding leadership in the union. It is reasonable for the Board to urge that it, as the expert

20 Joseph Dyson Co., 72 NL.R.B. 445 (1947) ; Lancaster Foundry Corp., 75 NL.R.B. 255 (1947); Copperweld Steel Co., 75 N.L.R.B. 188 (1947); Scullin Steel Co., 65 N.L.R.B. 1294 (1946).

21 American News Company, 55 N.L.R.B. 1302 (1944).

22 Thompson Products, Inc., 70 N.L.R.B. 13 (1946); 72 N.L.R.B. 886 (1947).

23 Mackay Radio Co., 96 N.L.R.B. No. 106 (1951).

24 E.g., Mackay Radio Co., ibid. 
administrative agency, should be permitted to resolve the factual dispute in such cases where the issue of discriminatory discharge must be determined by the Board. But the language of the Supreme Court in the Fansteel case suggests that it was the view of the Court that the sit-down strikers ceased to be employees because of their unlawful activities and were, therefore, no longer entitled to protection of the law..$^{25}$ If that be the case, then the employer need prove only the unlawful conduct to establish that the striker ceased at that time to be an employee and, therefore, lost his rights under the law. No amount of condonation thereafter would be effective to alter the situation, legally. ${ }^{28}$

In applying the condonation doctrine the Board has distinguished between strikes which are merely unprotected under the Act, such as a strike in breach of contract or strike activity characterized by violence, and strikes which are expressly contrary to provisions of the Act. ${ }^{2 \pi}$ An employer who condones activity which is merely unprotected may waive the right to discipline the strikers, but strikes which are contrary to the Act violate a basic public policy stated in the law, regardless of the employer's supposed condonation, and the Board will not order reinstatement of such unlawful strikers. The Board states that reinstatement and back pay to such strikers could effectuate the policy of the Act, but would place the Board in a position of encouraging conduct subversive of the statute.

Thus far we have reviewed briefly the protection afforded under the law to concerted activities and the type of activities which may not be protected. There is one further Board doctrine which should be referred to briefly before proceeding to a discussion of Section 8(b)(4) of the TaftHartley Act. The Board has devised the theory that employees who strike for purely economic reasons are economic strikers and may be displaced, but that those whose strike is caused or prolonged by unfair labor practices may not be displaced or discharged, at least in the absence of unlawful strike activity. ${ }^{28}$ This rule creates a further infringement of the employer's rights in case of a strike. Economic strikers continue to be employees, but they may be replaced and he may continue to operate his plant; but unfair labor practice strikers may not be replaced and if the employer tries to operate his plant and tries to displace unfair labor practice strikers, he will find that the Labor Board ultimately will direct him to discharge the replacement employees and reinstate the unfair labor practice strikers with back pay from the date they applied for and are refused reemployment after the termination of the strike. This rule certainly is drastic, but it can-

25 Supra note 17.

26 Consider also the case where an employer mistakenly believes an employee has committed acts during a strike for which he could lawfully be fired. If the employer fires lim, is the Board to decide only whether the motive of the employer was unlawful; or may it ignore the motive and find as a fact that the offense was not committed? Logically, the only issue should be the reason why the employer discharged the striker; if the motive was proper, the discharge is lawful, thougl made through error. It is as though a man were mistakenly fired for stealing; the discharge is unjust but not uulawful. But if this be so, is not the Board correct in arguing that the employer's motive is decisive even if unlawful acts were committed?

27 Mackey Radio Co., supra note 23.

283 N.L.R.B. ANr. Rep. 209 (1938); 2 CCH Lab. LAW SERV. 『 4035. 
not be said that it does not effectuate the policy of the Act to prevent unfair labor practices. ${ }^{29}$ Because of the stringency of the rule and the large amounts of back pay that were, in a few cases, paid because of it, there was a strong moveinent in Congress prior to the enactment of the Taft-Hartley Act to abolish the rule and to treat economic strikers and unfair labor practice strikers similarly. The effort failed, although Congress shook its finger at the Board. ${ }^{30}$

In fact, in view of the language of Section 9(c) (3) of the Taft-Hartley Act, the distinction under the Wagner Act between economic strikers and unfair labor practice strikers is preserved. That section provides in part:

Employees on strike who are not entitled to reinstatement shall not be eligible to vote.

As economic strikers are entitled to reinstatement but when replaced are no longer entitled to reinstatement, they would cease to be employees, and cease to be eligible voters upon replacement.

Unfair labor strikers on the other hand are unconditionally entitled to reinstatement in the absence of unlawful conduct. The Board, therefore, is compelled to decide in determining eligibility to vote in representation cases issues which can only be decided in an unfair labor practice case; that is, whether a particular strike is an economic strike or an unfair labor practice strike; and, further, whether particular employees who purportedly have been discharged or refused further employment because of allegedly unlawful activities were properly terminated because of their unlawful act or were improperly terminated and are entitled to reinstatement and, therefore, to vote. Merely to mention the problem is to indicate the variety of difficult situations which will inevitably arise. The Board will presume an economic strike unless the Board itself has found an unfair labor practice strike; and refusal of the General Counsel to issue a complaint conclusively establishes the strike to be economic. ${ }^{31}$

It is theoretically possible for an enployer faced with an economic strike to replace his striking employees with non-union employees and then successfully challenge the umion's claim to representation of a majority. ${ }^{\mathbf{2 2}}$

29 Cf. Potlatch Forests, Inc., 87 N.L.R.B. 1193 (1949) (preference to strikers returning to work during strike found unlawful by the Board), rev'd, National Labor Relations Board $v$. Potlatch Forests, 189 F.2d 82 (9th Cir. 1951).

80 See the Conference Report, H. R. ReP. No. 510, 80th Cong., 1st Sess. 6 (1947): "(C) The conference agreement does not contain the specific provisions of the House bill dealing with the status of "unfair labor practice" strikers. Since the different treatment of unfair labor practice strikers and economic strikers is simply a practice of the Board which the Board can change within the framework of the existing law, it was thought by the House managers that the Board should be given an opportunity to change this practice itself rather than needlessly complicating the definition of the tern 'employee.'

"In the National Silver Company case (71 NLRB 87) (1946) at least one member of the Board thought that the Board's pohicy should be to so use its powers as to encourage employees and their organizations to use the peaceful procedures under the act instead of resorting to the strike weapon. Such a policy would seem to be more in accord with the stated purpose of the act."

31 Times Square Stores Corp., 79 N.I.R.B. 361 (1948).

32 Granite City Steel Co., 87 N.L.R.B. 894 (1949); Midwest Screw Products Co., 86 N.L.R.B. 643 (1949); Old Line Life Ins. Co., 96 N.L.R.B. No. 66 (1951). 
The chances for settlement of a strike under such circumstances are practically nil. On the other hand, if the employer mistakenly believes that the strike is an economic strike whereas it is an unfair labor practice strike and refuses to bargain after replacement, he has not only refused to bargain with the union which probably continues to represent a majority, but he has discriminated against the employees who have lost their jobs because of their replacement by other workers. There is, therefore, some incentive for an employer to settle a strike where it is uncertain that the strike is economic and not an unfair labor practice strike.

$$
\text { THE TAFT-HARTLEY ACT, SECTION 8(b) (4) }
$$

So much for the right to strike under federal law and its normal consequences.

We turn now to a consideration of the prohibitions of the federal law and particularly to those under Section 8(b) (4) of the Taft-Hartley Act. The section reduced to its simplest terms forbids a labor organization or its agents to induce employees to engage in any concerted course of action for one of the forbidden purposes. With the possible exception of peaceful picketing or other similar conduct which could be protected as free speech, where it is only speech and not part of a course of conduct, all such concerted action is forbidden.

The forbidden objectives are the following:

(1) To force a self-employed person to join a labor or employer orgamization.

(2) To force an employer to join an employer or labor organization.

(3) To force an employer or other person to cease using the products or services of another employer. (This language, in effect, would forbid all secondary boycotts regardless of their purpose or objective.)

(4) To force an employer other than the employer of the striking (or otherwise concertedly acting) employees to bargain with an uncertified union.

(5) To force an employer to bargain with one union when another has been certified.

(6) To force an employer to assign particular work to employees in one labor organization or "trade craft or class" rather than another.

Congress in forbidding concerted activity for the objectives listed determined that these objectives were contrary to public policy, and that any concerted activity undertaken for such objectives should be prohibited. The attack made upon the legislation has been upon the following grounds, among others:

(1) That there is a constitutional right to strike which may not be prohibited.

(2) That certain of the objectives are not properly classified as illegal.

(3) That the statute is void because the language used is so broad and so anibignous that no definite standards are established to guide the Board in its decisions.

(4) That some forbidden concerted activity is constitutionally pro- 
tected (as for example, peaceful picketing) even though a strike might not be.

As we have seen, there is no constitutional right to strike and this right is subject to reasonable regulation. The Taft-Hartley Act appears to accoinplish reasonable accommodation of the rights of the public and the rights of organized labor, and regardless of any divergence of views as to the wisdom of the legislation, there is no reason to anticipate that any court will hold the law unconstitutional because it does limit the right to strike.

The argument made against the constitutionality of the law for uncertainty has been given short shrift by the courts. The inost ambiguous and unost uncertain section of the law, Section 8(b) (4) (A), was upheld against the uncertainty argument in the Ninth $^{33}$ and Second ${ }^{34}$ Circuits. The argument has little weight in any event in view of the language of the Supreme Court in United States v. Petrillo, upholding the constitutionality of the Lea Act (the so-called anti-Petrillo Act) as against a similar contention of uncertainty. ${ }^{\mathbf{3 5}}$

Any doubt as to the constitutional validity of prohibiting concerted activity for the specified unlawful objectives was removed by the Supreme Court in three cases, decided May $8,1950 .{ }^{36}$ The Court held that even picketing which is clearly peaceful may constitutionally be regulated or forbidden where the object is unlawful. The Court went so far as to hold that the objective may be declared unlawful not only by the legislature but also by the judicial determination of a state court. It is sufficient that the prohibition of peaceful picketing be necessary in order to effectuate a state policy established by law, which means either by the legislative or the judicial branch. The only limitation appears to be that the policy to be effectuated be of sufficient importance to outweigh the interest of the union in asserting its right to picket. So far as the Taft-Hartley Act is concerned, it appears clearly that there is no countervailing public interest in permitting the free play of economic forces which would be sufficient to outweigh the public interest in suppressing activity undertaken for the specified unlawful objectives.

\section{Picketing as "Speech"}

Another principal ground of attack is that peaceful picketing, the unfair list, and other types of conduct forbidden by the law constitute the exercise of free speech and are protected by the First Amendment as well as by the provisions of Section 8(c) of the Taft-Hartley Act. This argunient rests upon the theory that peaceful picketing is always free speech and, therefore, cannot be abridged; and a similar argument may be made for the unfair list and any other conduct evidenced by speech.

33 Printing Specialties and Paper Convert. U. v. Le Baron, 171 F.2d 331 (9th Cir. 1948).

34 National Labor Rel. Bd. v. Wine, Liquor \& Dist. Wkrs. U., 178 F. 2d 584 (2d Cir. 1949).

35332 U.S. 1 (1947). Cf., however, In re Blaney, 30 Cal.2d 643, 184 P. 2d 892 (1947).

See also Communications Assn. v. Douds, 339 U.S. 382 (1950), upholding the Taft-Hartley non-communist affidavit requirement against an attack on grounds of vagueness.

36 Hughes v. Superior Court, 339 U.S. 460 (1950); Teamsters Union v. Hanke, 339 U.S. 470 (1950); Building Service Union v. Gazzam, 339 U.S. 533 (1950). 
Peaceful picketing is under some circumstances the exercise of the right of free speech, but as a part of a course of coercive conduct it is not protected speech but partakes of the coercive nature of the conduct of which it is a part. The Supreme Court in Giboney v. Empire Storage Co. applied to picketing and other conduct of a umion evidenced by speech, the familiar "course of conduct" rule applied by the Labor Board under the Wagner Act in determining what speech by an employer is protected. ${ }^{3 n}$ The Court said: ${ }^{38}$

Thus all of appellants' activities-their powerful transportation combination, their patrolling, their formation of a picket line warning union men not to cross at peril of their union membership, their publicizing-constituted a single and integrated course of conduct, which was in violation of Missouri's valid law. ...

It rarely has been suggested that the constitutional freedom for speech and press extends its immunity to speech or writing used as an integral part of conduct in violation of a valid criminal statute. We reject the contention now.

This result was foreshadowed in Thomas v. Collins, where Mr. Justice Rutledge, writing for the Court, said: ${ }^{39}$

Accordingly decision here has recognized that employers' attempts to persuade to action with respect to joining or not joining unions are within the First Amendment's guaranty.... Decisions of other courts have done likewise. When to this persuasion other things are added which bring about coercion, or give it that character, the himit of the right has been passed. ... But short of that limit the employer's freedom cannot be impaired. The Constitution protects no less the employees' converse right. Of course espousal of the cause of labor is entitled to no higher constitutional protection than the espousal of any other lawful cause. It is entitled to the same protection.

In enforcing an NLRB order against a union found guilty of a secondary boycott under Section 8(b) (4) (A), the Supreme Court held that "signal picketing" was not protected free' speech, but amounted to a direction to strike. ${ }^{40}$ The decision treats the picketing as in the nature of conduct, rather than speech.

Where there was no pre-arranged signal, but only peaceful picketing, the Court upheld a similar order, stating: ${ }^{41}$

We find no indication that Congress thought that the kind of picketing and related conduct which was used in this case to induce or encourage a strike for an unlawful object was any less objectionable than engaging directly in that strike.

87336 U.S. 490 (1949)

88 Id. at 498.

39323 U.S. 516, 537 (1945).

40 Labor Board v. Denver Bldg. Council, 341 U.S. 675 (1951).

41 Electrical Workers v. Labor Board, 341 U.S. 694, 704 (1951). 
The Court went on to say, as to Section 8(c) protecting free speech: ${ }^{42}$

The remedial function of Section 8 (c) is to protect noncoercive speech by employer and labor organization alike in furtherance of a lawful object. It serves that purpose adequately without extending its protection to speech or picketing in furtherance of unfair labor practices such as are defined in Section 8(b) (4). The general terms of Section 8(c) appropriately give way to the specific provisions of Section 8 (b) (4).

The Court appears to suggest that speech in furtherance of a secondary boycott is unprotected, regardless of Section 8(c). Actually a holding to this effect is unnecessary. ${ }^{43}$ The Court concluded: ${ }^{44}$

The constitutionality of Section $8(\mathrm{~b})(4)$ (A) is here questioned only as to its possible relation to the freedon of speech guaranteed by the First Amendment. This provision has been sustained by several Courts of Appeals. The substantive evil condemned by Congress in Section $8(\mathrm{~b})(4)$ is the secondary boycott and we recently have recognized the constitutional right of states to proscribe picketing in furtherance of comparably unlawful objectives. There is no reason why Congress may not do likewise.

The courts, then, apply the same rules to "speech" by unions (peaceful picketing, the unfair list, or any other oral or written statements, including the statements on picket signs) that have been applied to "speech" by employers. The "speech" will not be viewed in isolation but will be considered in its setting, and if it be found that it is part of a coercive course of conduct forbidden by Section 8(b) (4), all of the unlawful activity, including the speech, will be unlawful and may constitutionally be enjoined.

This does not necessarily mean that speech or even peaceful picketing under all circumstances may be forbidden. The Court has not expressly abandoned its earlier decisions classifying peaceful picketing as free speech where it is speech and not part of a coercive course of conduct. The con-

$12 I d$, at 704 .

43 The Labor Board, believing that peaceful picketing was free speech, reached a rather anomalous result in its effort to accommodate Section $8(\mathrm{~b})(4)$ and Section $8(\mathrm{c})$ of the TaftHartley Act. Section $8(\mathrm{c})$ in essence provides that noncoercive speech shall not be, or be evidence of, an unfair labor practice under any of the provisions of the Act. The Board in Umited Brotherhood of Carpenters and Jomers, 81 N.L.R.B. 127 (CCH para. 8657), reasoned that Section 8 (c) should not be applied as a limitation upon Section $8(\mathrm{~b})$ (4) (A) because that section was broad enough to encompass and was intended to encompass and to forbid peaceful picketing in aid of a secondary boycott. Therefore, if the presumed Congressional purpose to prohibit peaceful picketing in aid of a secondary boycott was to be made effective, and if peaceful picketing was necessarily speech, and therefore could not be considered by the Board as evidence because of the limitation of Section $8(\mathrm{c})$, Section $8(\mathrm{c})$ had to be ignored in construction of Section $8(\mathrm{~b})$ (4) (A). The reasoning is unnecessary to a decision of the case as Section 8 (c) was intended to protect, and actually protects only noncoercive speech.

The Board, following its coercive course of conduct theory, should apply the same rule with respect to union conduct as free speech that is always applied in determining the legality of employer conduct which is evidenced in part by speecl. This result is suggested by the N.L.R.B.'s decisions in Juneau Spruce, 90 N.I.R.B. 1753 (1950), and Henry Shore, 90 N.L.R.B. 1768 (1950). There the Board recognized that "picketing-even peaceful picketing-has aspects which are more than speech, and that it may therefore be restricted, at least where it is undertaken for an unlawful objective." Id. at 1769-70.

44 Electrical Workers v. Labor Board, supra note 41 at 705. 
clusion seems inescapable, however, that in practice union conduct, including the unfair list, picketing, even mere publicity picketing, will be considered to be part of a course of conduct and therefore subject to restraint, whenever what the union has done is effective as economic pressure. Conversely, it would be recognized as constitutionally protected free speech only where it is ineffective as economic pressure and, therefore, futile.

\section{$N L R B$ Interpretation of Section $8(b)(4)(A)$}

The Board faces a serious problem in interpreting the portion of Section $8(\mathrm{~b})(4)(\mathrm{A})$ which forbids any concerted action of employees induced by a union where an object thereof is to force or require any person to cease doing business with any other person. The intention of Congress, according to Senator Taft, was to forbid all secondary boycotts by this section. ${ }^{40}$ However, Congress wanted to prevent the exercise of economic pressure upon employers only secondarily involved while presunably permitting the pressure to continue against the person who was the primary objective of the concerted action. Normally a strike, or a picket line, or the unfair list, will be intended to induce other persons to cease doing business with the primary employer; for example, to induce customers not to patronize or to induce transport companies not to deliver, or not to remove supplies or products. The object of any concerted action on an employer is to bring economic pressure to bear through damage to the employer's business, including business relations with third parties. The unfair list could have no other purpose. Therefore, in any primary strike the union intends as an object to induce third persons to cease doing business with the struck employer. The law on its face forbids such activity where the object is to "force or require" third persons to cease doing business with the struck employer. In any primary strike, the union intends, if it can, to require all persons to cease doing business with the struck employer by the exercise of economic pressure. The union intends more than persuasion; it intends its persuasion to be effective and, if the persuasion is effective, relations of the primary employer with third persons will necessarily be disrupted. The Board has construed the statute to apply only to secondary pressure and thus the Board has avoided decision of the serious constitutional problem which could arise if the statute were applied to forbid every effective primary strike, which would be the result of literal interpretation of the law.

This brings us, then, to a consideration of the interpretation which the Board has given to the law. Again, the section which is most important, giving rise to more decisions than any other because of its frequent use as an economic weapon, is the secondary boycott provision of Section 8(b) (4) (A). The law quite clearly forbids the product boycott-that is, economic pressure upon a secondary employer not to use or deal in the products of the employer primarily involved. For example, in United Brotherhood of Carpenters v. Sperry, the urion by picketing and the unfair list sought to bring pressure to bear upon the picketed employer not to use unfair pre-

4593 Cong. Rec. 4198 (1947); cf. H. R. Rep. No. 510, 80th Cong, 1st Sess. 43 (1947). 
fabricated houses; ${ }^{46}$ that is, to cease doing business with the manufacturer with which the union had a dispute.

In Printing Specialists and Paper Converters Union v. LeBaron, the union's picket line was intended to require the picketed employer to cease handling the products of an employer with which the union had a dispute, and thus unlawful because intended to require the secondary employer to refuse to handle the unfair products of the primary employer. ${ }^{47}$

Similarly, in the Distillery Workers case, the union sought to mduce the employees of neutral employers distributing Schenley products to refuse to handle them in order to force the neutral secondary employers, the distributors, to cease domg business with Schenley. ${ }^{48}$ The union had no dispute with the distributors and its only dispute was with the primary employer, Schenley.

In all of these cases the Board and the courts interpreted the law to forbid the conduct engaged in by the union. In the Distillery Workers case, the Court of Appeals for the Second Circuit upheld an NLRB finding of unfair labor practices; while in the decisions in the Ninth and Tenth Circuits which were entered prior to a Board decision, Taft-Hartley injunctions, issued pending consideration of the case by the Board, were upheld. Since the temporary injunctions were entered, there have been Board decisions in these cases and in all of them the Board found the union conduct to be unlawful. ${ }^{49}$

In cases of this type the neutral employer has no connection with the alleged unfair employer except through the product, and it may not be said that a primary labor dispute exists at the picketed premises. The employer primarily involved is not engaged in business at the picketed premises; and, even if the neutral employer ceases using the alleged unfair product, the primary dispute will not be settled. Nothing that the neutral employer can do will settle the primary dispute.

Limitation of Section $8(b)(4)(A)$ to Secondary Activity. The situation is otherwise, however, if the primary employer is engaged in doing business at the place where the economic pressure is applied and if the umon is seeking only to bring pressure to bear directly upon the employer with which it has a dispute. The Board's decisions are not entirely consistent but generally the Board has held that incidental, secondary effects do not make primary concerted action unlawful if the primary action occurs at a place where the primary employer is engaged in business.

This doctrine was first enunciated in the Pure Oil Company case..$^{50}$ In that case the union had a primary dispute with the Standard Oil Company which had leased space on its dock to the Pure Oil Company, a neutral employer. The union picketed the Standard dock and the picket line in-

46 170 F. 2d 863 (10th Cir. 1948).

47 Supra note 33 .

48 Supra note 34 .

19 United Brotherhood of Carpenters, 81 N.L.R.B. 802 (1949); Printing Specialties and Paper Converters Union, 82 N.L.R.B. 271 (1949).

5084 N.L.R.B. 315 (1949). 
duced employees of the neutral Pure Oil Company to refuse to work, with the result that their employer, Pure Oil, was required to cease doing business at the Standard Oil Dock and to cease using the premises of the Standard Oil Company. Picketing was conducted at the situs of the labor dispute; that is, at a place where there was a dispute with the primary employer. But the union incidentally had the intention of requiring the secondary employer to cease doing business with the Standard Oil Company. The Board held that Section 8(b) (4) (A) was not intended to curb traditional primary action and that as the picketing was confined to the Standard Oil premises, it was primary and permissive under the law. The Board, in addition, concluded that the union did not intend as an object to force Pure Oil to cease doing business with the Standard Oil Company but that this was merely a secondary effect and not an object of the union's primary pressure. Finally, in this case the Board upheld hot cargo letters sent by the striking umon to employees of oil tanker compames. The letters were direct appeals to employees of the tanker companies to refuse to handle Pure Oil cargo at the Standard Oil Dock. The Board held that the appeals contained in the letters, like the picketing, amounted to no more than a request to respect the primary picket line at the unfair employer's premises and thus constituted primary strike action.

The doctrine of the Pure Oil case has been developed and extended in several later cases. For purposes of convenience, the employer with which the union is in dispute will be referred to in this analysis as the unfair employer and the enployer who is not directly involved in the primary dispute will be referred to as the neutral employer.

In Ryan Construction Corp., the union picketed a plant of the unfair employer where a neutral contractor, Ryan, was at work. ${ }^{51}$ In addition to the main gate where the unfair enployer's employees entered the premises, the union picketed a gate used exclusively by Ryan employees. The neutral Ryan employees refused to cross the picket line and thus they were induced to refuse to work and to require their employer to cease doing business with the unfair enployer. The Board held the union's activities were protected primary activity even at the Ryan gate as that gate could be used by other employees as well as by Ryan employees.

In Schultz Refrigerated Service, the union picketed the unfair employer's trucks at the place of business of the unfair employer's customers. $^{52}$ The picketing was limited to the unfair employer's trucks and the neutral custoniers' premises were not picketed nor was there any picketing when the trucks were not present. The Board held the action was primary action as the peripatetic unfair employer was doing business wherever his trucks called.

In Sterling Beverages, Inc., the union picketed the unfair employers' trucks at the place of business of a neutral customer but also picketed the customer's premises for brief periods before and after the trucks arrived. ${ }^{63}$

\footnotetext{
5185 N.L.R.B. 417 (1949).

6287 N.L.R.B. 502 (1949).

6390 N.L.R.B. 401 (1950).
} 
The Board held picketing of the trucks was primary action and protected but that the union violated the law when it picketed the neutral employer's premises when the trucks were not present.

One distinction between the Schultz and the Sterling cases to which the Board appeared to give no weight was the fact that in the Schultz case the union was the bargaining representative of the enployees of the unfair employer, while in the Sterling case it was not but sought by picketing to induce recognition as bargaining agent of the eniployees, none of whom were members of the picketing union.

In Interborough News Company, the union picketed news stands operated by an unfair employer and, in addition, requested the employees of various neutral publishers and distributers servicing the news stands not to make deliveries. ${ }^{54}$ The Board upheld the union action on the ground that it was primary activity intended to induce eniployees of neutral employers not to perform services at the premises of the unfair employer.

The vital factual question in all these cases is the existence of a primary labor dispute at the neutral employer's premises. This necessarily presupposes that both the unfair employer and the neutral employer are donig business at the same premises and that the situs, or at least a situs, of the primary labor dispute is also a place of business of a neutral entployer as to whom there is no dispute.

In Moore Dry Dock Company, the union picketed a ship owned and operated by an unfair entployer while it was in a ship repair yard owned and operated by a neutral employer. ${ }^{55}$ The situs of the labor dispute was the ship and the picketing was limited insofar as possible to the ship. All work in the ship repair yard, except work on the particular ship, continued and it appeared that the employees, or at least some of the employees, of the unfair employer were at work on the ship while the picketing was going on. The trial examiner held that the union was engaged in lawful primary activity as the unfair employer was engaged in business at the ship repair

E4 90 N.L.R.B. 2135 (1950).

5592 N.L.R.B. 547 (1950). The test applied is stated by the majority as follows: "In the kind of situation that exists in this case, we believe that picketing of the premises of a secondary employer is primary if it meets the following conditions: (a) The picketing is strictly limited to times when the situs of dispute is located on the secondary employer's premises; (b) at the time of the picketing the primary employer is engaged in its normal business at the situs; (c) the picketing is limited to places reasonably close to the location of the situs; and (d) the picketing discloses clearly that the dispute is with the primary employer." Id. at 549.

Each of these elements must be present. In Richfield Oil Corporation, 95 N.L.R.B. No. 160 (1951), the union picketed the premises of a secondary employer where the primary employer was engaged in installation work. The picket signs disclosed the dispute was with the primary employer but the union extended the dispute to the neutral secondary employer by (I) telling a trucking company's employees delivering goods to the neutral employer that they could cross the picket line only because they were in transit before the picket line was set up; (2) pickets replied evasively to persous having business with the secondary employer who inquired about crossing the picket line; and (3) attempts were made to interfere with other work in progress on the secondary employer's premises. There was no request by the union to place the picket lines inside the neutral secondary employer's plant at the situs of the dispute as in the Moore Drydock case. The entire course of conduct of the union slowed that it was an object of the picketing to bring pressure to bear on the neutral secondary employer in order to force hun to cease doing business with the unfair primary employer. 
yard even though that was primarily the place of business of the neutral employer. The Board, in a three to two decision agreed, holding that the picketing was primary, as the unfair employer's employees were actually at work on the picketed premises.

In summary, picketing at the situs of a labor dispute is normally intended to bring economic pressure to bear on the primary employer, the unfair employer, at the place where the allegedly unfair labor conditions exist. If economic pressure is directed primarily at the allegedly unfair employer, the Board holds that any secondary pressure on neutral employers who may also be doing business there is incidental and lawful.

If the place picketed is the regular place of business of the unfair employer as in the Pure Oil and Ryan cases, the fact that a neutral, secondary employer may also do business there does not make pressure on the unfair enployer unlawful. In these cases, the situs of the labor dispute is a regular place of business of both the neutral and the unfair employer and so long as the picketing is directed only at the unfair employer it is lawful.

Where the picketing is conducted at the regular place of business of a neutral employer, which is also a temporary or transitory place of business of the unfair employer, picketing directed only at the unfair employer during the time when he is doing business there is lawful even though it be true, as it often is, that pressure is intended to be brought also upon the neutral employer.

Judicial Approval of NLRB Interpretation of Section $8(b)(4)(A)$. If a fair primary contractor employs an unfair subcontractor, the relations of contractor and subcontractor working on the same job raise many complex problems, ${ }^{56}$ and picketing of the job site is generally intended to force the neutral, primary contractor to cease doing business with the unfair subcontractor. Nevertheless, the dispute is primary and the union's pressure is directed to a place where the unfair employer is engaged in business and where the allegedly unfair conditions exist. The object of the union's action is to force the unfair employer to remedy the unfair conditions although necessarily there is pressure also on the neutral employer to cease doing business with the unfair employer if he should refuse to remedy the unfair conditions.

Before the decision in the Pure Oil case, the Board had held in several such cases that a union violated the Act when it picketed a construction site where an unfair subcontractor was employed. In the Samuel Langer case, decided April 12, 1949, two months before the Pure Oil case, the union picketed a private residence where carpentry work had been let to a fair contractor and the electrical work to an unfair contractor. ${ }^{57}$ The umon picketed, however, only when the employees of the fair employer, the carpenter, were at work so that the pressure was directed at the fair contractor in an effort to force hini to cease doing business with the unfair

56 See Woll, Glenn \& Thatcher, Secondary Boycott Provisions Clarified, 2 CCH LAB. LAw J. 677 (1951).

$6 \pi 82$ N.I.R.B. 1028 (1949). Board order enforced in Electric Workers v. Labor Board, supra note 41. 
electrical contractor. The fact that no employees of the unfair employer were working was held decisive by the Court of Appeals for the Second Circuit in enforcing the Board's order. ${ }^{58}$ The court of appeals left open the question whether the picketing would be lawful if the unfair employer had also been at work when the union picketed. The Supreme Court in affirming the court of appeals noted that: ${ }^{59}$

There are no findings that the picketing was aimed at Langer to force him to employ union workmen on this job. On the contrary, the findings demonstate that the picketing was directed at Deltorto's employees to induce them to strike and thus force Deltorto, the carpentry subcontractor, to force Giorgi, the general contractor, to terminate Langer's electrical subcontract.

In the Gould and Priesner case, decided the day after the Langer case, the Board found unlawful the picketing of a building project on which the union main contractor had employed a nonunion electrical subcontractor, but with all of the other work being done by union men. ${ }^{60}$ The union picketing was conducted at a tinie when the employees of the unfair employer were at work as well as the union employees, but the picketing was directed at the fair primary contractor. The Board's decision could be reconciled with the Pure Oil case on the theory that the prine contractor was a neutral and that the action of the union was directed at him and not at the nonunion contractor. When the nonunion contractor was removed from the job, picketing ceased so that the action of the union was intended to force the nonunion contractor off the job. The Court of Appeals for the District of Columbia refused to enforce the Board's order and set it aside, holding that the picketing was primary activity at the situs of the labor dispute and therefore protected; and, further, that the primary contractor was not a neutral but actually became a party to the dispute when he brought the employees of the unfair eniployer upon the job. ${ }^{61}$

The Supreme Court reversed, holding that the union picketed the primary contractor in order to force hin to cease doing business with the nonunion subcontractor and thus violated Section $8(\mathrm{~b})(4)(\mathrm{A})$. An object of the union's picketing was to force the contractor to terminate the subcontract with the nonunion firm, and the Court held that the relations of contractor and subcontractor did not make the eniployees of one the employees of the other. The Court said: ${ }^{62}$

The business relationship between independent contractors is too well - established in the law to be overridden without clear language doing so.

The Court gives controlling weight to the Board's interpretation of Section 8(b) (4) (A), and in effect says that when the Board had found the

58 International Brotherhood v. National Labor Rel. Bd., 181 F.2d 34 (2d Cir. 1950).

50 Supra note 41 at 699.

6082 N.L.R.B. 137 (1949), enforcement granted, Labor Board v. Denver Building Council, 341 U.S. 675 (1951), reversing, 186 F. 2d 326 (D.C. Cir. 1950). 1950).

${ }^{61}$ Denver Bldg. and Const. Tr. C. v. National Labor Rel. Bd., 186 F.2d 326 (D.C. Cir.

B2 Supra note 40 at 690 . 
conduct in question to be secondary, the Board's interpretation "in doubtful situations" should not be overturned by a court of appeals.

The weight given the Board's interpretation is also underlined by the Supreme Court's decision reversing the Fifth Circuit in Labor Board v. Rice Milling $\mathrm{Co}^{\mathrm{B3}}$ The court of appeals remanded for further consideration a case in which the Board had held that a union's conduct was primary protected activity when, in the course of picketing the plant of an unfair employer, it induced the employees of a neutral trucking company not to enter the premises of the unfair employer. The court of appeals held that it was immaterial that the action took place at the situs of the primary labor dispute. It said that the statute was violated so long as a purpose of the union was to induce the neutral employer to stop doing business with the unfair employer in order to force the unfair employer to submit to the demands of the union.

The case was decided by the Supreme Court on the narrow ground that the respondent urion, by its picketing, encouraged cessation of work by only two individual employees, and that there was no inducement of "concerted," as against "individual," action. The Court noted that the picketing was at the situs of the primary dispute, and that "insofar as the union's efforts were directed beyond that and towards the employees of any one other than Kaplan, there is no suggestion that the umion sought concerted conduct by such other employees." 64

The Court suggested approval of the reasoning of the Board in the Pure Oil case, ${ }^{65}$ stating: ${ }^{86}$

... There were no inducements or encouragements applied elsewhere than on the picket line. The limitation of the complaint to an incident in the geographically restricted area near the mill is significant, although not necessarily conclusive. The picketing was directed at the Kaplan employees and at their employer im a manner traditional in labor disputes. Clearly, that, in itself, was not proscribed by Sec. 8(b) (4) . . . A union's inducements or encouragements reaching individual employees of neutral employers only as they happen to approach the picketed place of business generally are not aimed at concerted, as distinguished from individual, conduct by such employees. Generally, therefore, such actions do not come within the proscription of Sec. 8(b) (4), and they do not here.

The question was not presented nor decided but this language foreshadows approval of the Board's interpretation of Section 8(b)(4)(A). In the absence of any contrary Supreme Court decision the Board undoubtedly will continue to follow the same line of reasoning, and the courts of appeals may be expected to approve the Board's resolution of the complex problem of interpreting Section 8(b) (4) (A).

Other Limitations on Section $8(b)(4)(A)$. Umions are only forbidden to mduce employees to engage in the prohibited conduct. There is no inter-

\footnotetext{
63341 U.S. 665 (1951), reversing 183 F. 2d 21 (5th Cir. 1950).

64 Id. at 671 .

05 Text at note 50 supra.

${ }^{68}$ Supra note 63 at 671 .
} 
diction against inducing such forbidden acts by an employer or by the general public. The Board, therefore, has held that the union may speak directly to an employer to induce him to cease doing business with another employer. The union may not bring pressure to bear on the employer through concerted action of his employees, but it may try to induce him by communications to supervisors or other management representatives, to cease doing business with the third person. For example, in Rabouin $D / B / A$ Conway's Express, the Board held that a request by a union representative addressed to other companies that they not handle the freight of a company with which the union had a labor dispute was not unlawful inasmuch as the union did not seek to induce any employees to refuse to handle the freight, but expressed itself exclusively to supervisors or other representatives of management. ${ }^{67}$

The Board further qualified the law in this same case by holding permissible a union's enforcement of a hot cargo clause in its collective bargaining contract with other employers whereby they agreed that the union could refuse to handle goods of an employer involved in a labor dispute. There the union advised employees of the secondary employers of the existence of a strike against Rabouin (that Rabouin freight was "hot") and the employees then stopped handling Rabouin freight. This action was quite clearly such as would be held unlawful by the Board in the absence of any such hot cargo clause in a contract. The Board stated, however: ${ }^{68}$

This section does not proscribe other means by which unions may induce -employers to aid them in effectuating secondary boycotts; much less does it prohibit employers from refusing to deal with other persons, whether because they desire to assist a labor organization in the protection of its working standards, or for any other reason. An employer remains free under that section of the amended Act, as always, to deal with whatever firms, union or nonumion, he chooses. And by the same token, there is nothing in the express provisions or underlying policy of Sec. 8(b) (4) (A) which prohibits an employer and a umion from voluntarily including "hot cargo" or "struck work" provisions in their collective bargaining contracts, or from honoring these provisions. That is all that happened in this case. We therefore find that the respondent did not violate Section $8(\mathrm{~b})(4)(\mathrm{A})$ of the Act by causing employees of Palmer Lines, Central Warehouse, and Openheimer and McEwan to exercise their contractual privilege of declining to handle Conway freight.

The clause in the contract mvolved in this case was inserted before the Taft-Hartley Act became effective, although the Board does not rely on that circumstance. The case leaves for later decision, however, the validity of such a clause in a contract negotiated after Taft-Hartley. Presumably, it would be valid and would be honored by the Board as a defense if voluntarily agreed to by the employer; and if in addition it appeared that the employer voluntarily accepted the union's interpretation of the contract as justifying refusal by his employees to handle the hot cargo. On the other hand, if the employer is required by strike action or by a threat of a strike

6787 N.L.R.B. 972 (1949).

68 Id. at 982 . 
to honor such a clause or to insert such a clause in a contract being negotiated, a different result might follow as the conduct of the union would fall within the express language of Section 8(b) (4) (A).

As noted above, the Board has interpreted the law as not forbidding incidental (although intended) secondary effects of a primary labor dispute. Thus, if the union's concerted action is directed primarily at the employer with which it has a dispute, the provisions of the law have not been violated. The Board has carried this doctrine further and has held that the employer, in order to avail itself of the protection of the section, must be a neutral or wholly unconcerned employer. One federal district court has reached a similar result.

The language of the statute forbids the inducement of employees to strike in order to force their employer to cease doing business with "any other person." If the supposed neutral secondary employer is actually an ally of the primary employer to such an extent that it is involved as much in the primary dispute as the primary employer, the restrictions of the law do not apply. The language of the statute contains no such exceptions but this construction is probably in accord with congressional intent.

The application of the principle is not easy. In Douds v. Metropolitan Federation, District Judge Rifkind refused an injunction requested by the Board's General Counsel to forbid picketing of a claimed neutral employer where it appeared that the employees of this employer, after a strike called against a primary employer, performed work which was formerly done by the strikers. ${ }^{69}$ The struck firm, in effect, purchased the services of the employees of the so-called neutral employer and furnished some supervision. About 75 per cent of production came from the struck employer. The Court found: ${ }^{\text {To }}$

I am unable to hold that corporate ownership or insulation of legal interests between two businesses can be conclusive as to neutrality or disinterestedness in a labor dispute.

The evidence is abundant that Project's employees did work, which, but for the strike of Ebasco's employees, would have been done by Ebasco. The economic effect upon Ebasco's employees was precisely that which would flow from Ebasco's hiring strike-breakers to work on its own premises. The conduct of the union in inducing Project's employees to strike is not different in kind from its conduct in inducing Ebasco's employees to strike. If the latter is not amenable to judicial restraint, neither is the former. In encouraging a strike at Project the union was not extending its activity to a front remote from the immediate dispute but to one intimately and indeed inextricably united to it.

This decision naturally suggests the possibility that any subcontractor of a struck employer could be found to be an ally and not a neutral. The Board, however, said "no" in Climax Machinery. ${ }^{71}$ The union there directed the employees of a subcontractor to refuse to handle work sent from

\footnotetext{
6975 F. Supp. 672 (S.D.N.Y. 1948).

70 Id. at 677 .

7186 N.L.R.B. 1243 (1949).
} 
a struck employer. For some two years before the strike, the subcontractor had done this type of work for the primary employer. The trial examiner analyzed in detail the congressional intent and the practical purpose which Congress had in mind as applied to the facts of the case under consideration and concluded that the subcontractor was really not primarily involved in a labor dispute and that there was a violation of the law. There actually was intended secondary pressure against the subcontractor and not merely an incidental extension of primary action undertaken against the struck employer. The union asked nothing of the secondary employer except that it cease doing business with the primary employer; the purpose of the pressure on the secondary employer was to induce action by the primary employer. The Board adopted the trial examiner's recommendations and conclusions, including the following: ${ }^{72}$

What the issue really boils down to is this: Does Section 8(b) (4) (A) apply to normal business dealings between a contractor and a subcontractor, both engaged in the same general business, where boycott pressure is applied against the subcontractor in aid of a dispute with the principal contractor? Clearly it does under the wording of the statute. And I am unable to agree with the [unions] that to construe the statute literally and apply it to this situation would be 'plainly at variance with the policy of the legislation as a whole.' In enacting 8 (b) (4) (A), Congress showed no disposition to distinguish between different kinds of secondary pressure. . . . The Board in building construction cases in effect has already taken the position sub silentio that contractors and subcontractors are not allies who fall outside the scope of Section $8(\mathrm{~b})(4)(A)$. No reason appears why a different rule should be applied to cases in other industries.

Following the reasoming of Judge Rifkind in the Metropolitan Federation case quoted above, the Board held in Irwin-Lyons Lumber Company, that a company which was wholly owned and managed by the same persons as a primary employer was not a "neutral or wholly unconcerned employer" and, therefore, pressure on its employees to strike in aid of a dispute with a primary employer was not unlawful. ${ }^{73}$ The reasoning appears to disregard the language of the law and to give effect to a presumed congressional intent to outlaw only secondary pressure; and not to protect parts of a business in fact primarily involved, despite some difference in the corporate or other form of business ownership.

Every action taken by a umon which may have secondary efforts is not forbidden. The Board in an early case, Osterink Construction Co., held it a violation of Section $8(\mathrm{~b})(4)(\AA)$ to place a primary employer on an unfair list, ${ }^{74}$ but in Grauman Co. this decision was overruled and the Board held that placing of a primary employer on an unfair list was not in and of itself a violation of Section $8(\mathrm{~b})(4)(\mathrm{A}) \cdot{ }^{75}$ Concededly, the placing of the

\footnotetext{
T2 Id. at 1252 .

7387 N.I.R.B. 54 (1949).

74 82 N.L.R.B. 228 (1949).

7587 N.L.R.B. 755 (1949).
} 
primary employer on the unfair list would have an effect upon employees of neutral secondary employers. The Board stated: ${ }^{70}$

The realities of labor-management relations require that, where the Act does not deny unions the right to engage in traditional direct activities in support of labor disputes, tliey should also be licensed to publicize such activity. We conclude, therefore, that a labor organization's activity in placing a primary employer on its unfair list is not automatically and per se violative of the amended Act.

Nor do we believe that other activity by a labor organization or its agents, whether related to the unfair list or not, can operate to convert into an unfair labor practice the otherwise protected character of the unfair listing of a primary employer. The existence of such an unfair list nuay be used, as it was in this very case, as the occasion for illegal conduct by union officials in inducing and encouraging employees to strike against secondary employers with whom the union is not in dispute. In such case, the unfair list may indeed be relied upon as evidence in assessing the propriety of the union's other conduct. However, the legality of the unfair list itself can no more be impaired than primary picketing can itself become unlawful because union agents refer to it in calling a secondary strike.

Following this reasoning, the Board in Western, Inc., held lawful the promulgation of an unfair list at a union meeting. ${ }^{77}$ But the union violated Section 8(b)(4)(A) and (B) when it induced employees of secondary employers to refuse to handle goods of the primary employer by advising them over the telephone of the unfair listing.

The Board explained its reasons for drawing the line at this point in the following extracts: ${ }^{78}$

... There is a valid support in practical human experience, althougl perhaps not in abstract logic, for prohibiting a union, as we have done, from telling a specific employee at his place of work about an unfair list, and yet holding the promulgation of that unfair list at a union ineeting to be lawful. ... As we indicated in the Grauman case ... , it is traditional primary action for a umion, withm its own councils, to classify a primary employer as unfair, whereas conveying the same information to a secondary employer's employee at his place of work assumes the aspect of unlawful secondary inducement tantamount to a specific direction to cease work.

Compare the "hot cargo" letters in the Pure Oil case. ${ }^{78 a}$ The Board pointed out that actually the hot cargo letters amounted to no more than an appeal to the employees of the secondary employer to observe the umon's primary picket line, like the appeal made by pickets before the premises of a primary employer. The appeal in this case was directed to the situs of the dispute, whereas in Western, Inc. the appeal requested support away from the situs. Similarly, where a union places the secondary employer on the unfair list, the Board has found a violation of Section $8(\mathrm{~b})(4)(\mathrm{A}) .^{70}$ This

\footnotetext{
76 Supra note 75 at 757 . (Emphasis added.)

7793 N.L.R.B. No. 40 (1951).

78 Ibid.

$78 a$ See text at note 50 supra.

79 United Brotherhood of Carpenters and Joiners, 81 N.L.R.B. 802 (1949).
} 
decision was based on the view criticized above that Section $8(\mathrm{c})$ protecting free speech did not limit Section 8(b) (4)(A).

Clearly, however, the addition of the secondary employer to the unfair list was part of a coercive course of conduct intended to bring indirect pressure to bear through the secondary employer and was not a part of the union's legitimate pressure upon the primary employer. In the Grauman case, ${ }^{70 a}$ the Board cites the Western, Inc. case as one in which the Board held unlawful the placing of the secondary employer on the unfair list.

In DiGiorgio Wine Co., all of the members of the striking union were agricultural workers and not "employees" as defined in the Act. ${ }^{80}$ Therefore, the striking union was not a labor organization within the meaning of the law, and the case against it was dismissed. Secondary activity of other unions was found unlawful, although primary activity having a secondary effect was held lawful.

Likewise, picketing and boycotting by a union representing only supervisors would not be forbidden inasmuch as supervisors are not employees within the nieaning of the law.

A somewhat parallel situation arose in the case of Schneider, Inc., where the Board dismissed a case in which picketing of a school board job was alleged to be a violation of Section 8 (b) (4) (A). The school job was being done by an unfair employer with which the union was in dispute. The action was secondary but the Board held that there was no pressure on "an employer or other person" within the meaning of the law because the school board was not a "person" but was a sovereign government agency. For similar reasons in International Rice Milling Company, Inc., the Board held there was no violation of Section 8(b) (4) (A) where the striking union sought to induce railroad employees to refuse to cross picket lines in the course of their duties for the railroad company. a secondary boycott by "employees" of an "employer" and neither the railroad employees nor the employer is such under the Taft-Hartley Act.

The Fifth Circuit reversed and remanded to the Board, holding that the words "any eniployer" referred to employers as a class rather than to employers as defined in the statute. ${ }^{83}$ The Board sought certiorari on another issue on which the Supreme Court reversed, ${ }^{84}$ but the Board accepted the remand on this question. The Board adopted the trial examiner's finding (which it had overruled in its first decision) that the union's picketing of the railroads violated the law. ${ }^{85}$ The trial examiner's report, the reasoning of which was accepted by the Fifth Circuit in overruling the Board, contains a complete and logical analysis of the problem.

However, the Fifth Circuit's decision and the Board's acceptance of it

79a Supra note 75.

8087 N.L.R.B. 720 (1949), enforcement granted, DiGiorgio Fruit Corp. v. National Labor Relations Bd., 191 F. 2d 642 (D.C.Cir. 1951).

8187 N.L.R.B. 99 (1949).

8284 N.L.R.B. 360 (1949), enforcement granted, 341 U.S. 665 (1951) (see text at note 63 supra).

83183 F. 2d 21 (5th Cir. 1950).

84 Labor Board v. Rice Milling Co., supra note 63.

85 International Rice Milling Company, Inc., 95 N.I.R.B. 186 (1951). 
probably does not settle the problem of whether "any employer" in Section $8(\mathrm{~b})(4)(A)$ is intended to mean employers as a class or to refer to employers as defined in the statute. The question is an important one and the definitions of employer (Section 2(2)) and employee (Section 2(3)) suggest many ways in which it may arise.

It is argued that secondary boycotting of any employer not subject to the Taft-Hartley Act, even though by a union representing employees whose employers are subject to the Act, is not contrary to the law; that neither an employer engaged solely in intrastate commerce, nor his employees is covered by the Taft-Hartley Act, so that a secondary boycott of an intrastate employer doing business with an unfair interstate employer is not touched by the law. But this argument fails since intrastate employers are not excluded from the definition of "employer," so that if the primary employer is engaged in commerce, secondary activities against an employer engaged solely in intrastate commerce are unlawful. ${ }^{86}$

\section{Primary Activity Forbidden by Section 8(b)(4)(A)}

Section 8 (b) (4) (A) not only forbids secondary pressure, but also forbids a union to induce employees to engage in concerted action in order to require a self-employed person to join a labor or employer organization or to force an employer to join a labor or employer organization. The first prohibition appears to conflict directly with the Supreme Court's decision in Bakery Drivers Local v. Wohl. ${ }^{8 i}$ There the Supreme Court upheld picketing as constitutionally protected, although the objective of the union by the picketing was to force bakery drivers who were self-employed either to join the union or to observe union conditions and employ a union driver one day a week. New York enjoined the conduct and the Supreme Court held that the picketing was constitutionally protected and could not be enjoined. Whether or not Wohl was overruled by the Gazzam and Hanke decisions ${ }^{88}$ clearly the $W o h l$ case will be no obstacle to judicial approval of this section of the law. In Wohl, New York had not declared the objective unlawful while Congress has done so expressly. In Wohl the picketing was viewed in isolation while in a Taft-Hartley case it would be considered as part of a course of conduct charged as an unfair labor practice. Finally, in the Hanke case, the Supreme Court in footnote five refers to Section $8(\mathrm{~b})(4)(A)$ as an instance of an unfair labor practice similar in nature to the conduct forbidden in Hanke.

So far as concerns the prohibition of concerted action to force an employer to join an employer organization, the Restatement of Torts, Section 793, declares such an objective to be illegal. The same result was reached in an early California case, Overland Pub.Co. v. H. S. Crocker Co., where the court held it to be an unlawful combination in restraint of trade for

86 Carpenters Union v. Labor Board, 341 U.S. 707 (1951), affirming 181 F.2d 126 (6th Cir. 1950), enforcing 80 N.L.R.B. 533 (1948); cf., Jamestown Builders Exchange, Inc., 93 N.L.R.B. No. 51 (1951), and Note, 2 CCH LAB. LAW REP. If 14,046 (1950).

87315 U.S. 769 (1942).

88 Supra note 36. 
a union and a printing employers' association to agree that the union members would not work for anyone who was not a member of the association, the purpose of the combination being to force all employers to join the employers' association. ${ }^{89}$

Undoubtedly, this objective also is properly classified as unlawful and contrary to public policy, and any concerted activity undertaken in violation of this subsection could be prohibited.

Section $8(b)(4)(B)$

Section $8(\mathrm{~b})(4)$ (B) forbids concerted activity by a labor organization for the purpose of forcing employees to strike im order to force another employer to bargain with an uncertified union. It is readily apparent that what this section is aimed at is secondary action to force an employer to bargain with an uncertified union and, therefore, Section 8 (b)(4)(A) in forbidding all secondary action, forbids also secondary action for the purpose prohibited by Section 8 (b) (4) (B). All of what has been said above, therefore, in considering Section 8 (b) (4) (A) is applicable also to Section 8 (b) (4) (B). In addition, the prohibition of this particular objective has a sound basis in policy. The National Labor Relations Act, as amended, provides for adjustnent of questions of representation and requires bargaming with the union thus selected. Section $8(\mathrm{~b})(4)(B)$ thus requires resort to the Board for settlenient of the question of representation to the limited extent that it forbids secondary pressure on the employer to require bargaining. ${ }^{00}$ Of course, a primary strike by the employees seeking recognition is not forbidden. All that is forbidden is extension to neutral employers of the dispute between the primary employer and his employees, and in thus confining the area of the dispute Congress seems to have acted within permissible bounds under the authorities discussed above.

Section $8(b)(4)(C)$

Section 8 (b) (4) (C) forbids a labor organization to induce employees to engage in concerted activity in order to force any employer to bargain with one umion when another has been certified. Quite clearly, this objective is unlawful and even under the Wagner Act the Labor Board held unlawful a strike to force an employer to bargain with one union when another had been certified. ${ }^{91}$ However, the Second Circuit in a curious decision has cast considerable doubt on the practical importance of this section. In Douds v. Local 1250, the Second Circuit affirmed an injunction granted to prohibit picketing by Umion A after certification of Union $\mathrm{B} .{ }^{{ }^{22}}$ Thereafter, Union A applied to the company for reinstatement of some 51 strikers and when its terms for reinstatement were not accepted, it resumed the

\footnotetext{
88193 Cal. 109, 222 Pac. 812 (1924).

90 However, there may be a violation of Section $8(\mathrm{~b})(4)$ (B) even though the N.L.R.B. has no power to determine the question of representation. See DiGiorgio Wime Company, supra note 80, and Moore Drydock Company, supra note 55. See, particularly, intermediate report in Moore Drydock Company.

01 Thompson Products, supra note 22.

92170 F.2d 695 (2d Cir. 1948).
} 
picketing. The district court found Union $A$ in violation of the decree, but on appeal the adjudication of contempt was reversed. ${ }^{.3}$ The injunction as affirmed by the Second Circuit actually forbade Union A to picket for the purpose of forcing the employer "to recognize or bargain with respondent [Union A] as the collective bargaining agent of any of the employees in the unit." Literally, therefore, the injunction forbade the later picketing engaged in by the union as it was for the purpose of requiring the employer to bargain with the union as a representative of the striking employees with regard to their reinstatement. The Second Circuit held that the picketing was not forbidden by the injunction and, therefore, implicit in the determination is the finding that the picketing is not an unfair labor practice under Section $8(b) .(4)$ (C). The court reasoned that Section 9(a) of the law permitted a minority union to assist its members in adjusting their individual grievances including grievances such as that for reinstatement in this case and that the picketing, therefore, was justified.

The proviso to Section 9(a) permits individual employees or a group of employees to present grievances to their employer and to have them adjusted without the intervention of a bargaining representative. The section does not permit nor require or even contemplate dual bargaining, such as the Second Circuit protected in this decision.

The purpose of Congress was to permit individual employees to have their grievances adjusted by talking directly to the employer; it was not the intention of Congress nor should the language be interpreted to require or permit bargaining with two unions at the same time.

If the decision is carried to its logical extreme, it means that an employer may bargain with a minority union regarding grievances, even though the law requires him to bargain exclusively with the union which represents a majority. Such a result is obviously nonsense and perhaps this decision is an excellent illustration of the wisdom of Congress in providing in the Wagner Act that the decision on such matters as this, which involves a consideration of the realities of collective bargaining, should be left to the expert judgment of the National Labor Relations Board and should not be lodged, at least in the first instance, in courts. That is one of the unfortunate defects of the National Labor Relations Act as amended by the Taft-Hartley law; that is, that the courts will more and more be called upon to give their interpretation of the law. The result will be a group of conflicting decision, including decisions such as the Local 1250 case, and the tangled mess of our labor relations law will become even more tangled.

The case actually is even more illogical as it offers a ready device for the evasion of the requirements of Section $8(\mathrm{~b})(4)$ (C). All the losing union has to do is to picket for the purpose of requiring the employer to adjust grievances with it and once having its nose under the tent, it can engage in a contest with the union recently certified by the Board which, if it will not result in the ultimate victory of the union which lost the election, will, at least, keep the labor relations of the employer in such an unsettled state

${ }^{83}$ Douds v. Local 1250, 173 F. 2d 764 (2d Cir. 1950). 
that the union which won the election will not be able to represent the eniployees effectively. ${ }^{94}$

\section{Section $8(b)(4)(D)$}

The final section, 8(b)(4)(D), forbids a union to induce employees to engage in concerted action for the purpose of forcing an employer to assign particular work to one labor organization or group of employees rather than to another. This prohibition, simply stated, prohibits concerted activity to obtain work assignments-normally a jurisdictional dispute. The law provides a rather complicated nuethod for deciding the jurisdictional dispute. Under the procedure adopted by the Board, a hearing will be held under Section $10(\mathrm{k})$ to determine the question of the right of the picketing union to demand the work. If the Board finds the union has no right to demand the work and it continues to picket, the Board then will proceed to issue a complaint under Section $8(\mathrm{~b})(4)(\mathrm{D})$. However, if the union abides by the Board's decision, the charge is dismissed..$^{95}$

In one case, the Board quashed a notice of hearing which was issued under Section $10(\mathrm{k})$ as a part of the preliminary determination of the question of jurisdiction, where the Board found that the picketing which gave rise to the filing of the charge of violation of Section 8(b) (4) (D) and to the notice of hearing under Section $10(\mathrm{k})$ was not for the purpose of requiring the employer to assign work to members of the picketing union but was rather for the purpose of requiring the employer to pay union wages. ${ }^{96}$ In that case, it appeared that the CIO union, which was doing the work, had a wage scale considerably lower than that of the AFL union which was picketing. It is reasonable to suppose that if the employer paid the higher AFL scale, he would hire the probably better qualified AFL employees, so the net result of the picketing might be to require the assignment of the work to the AFL. However, there was no showing that the union sought to force the employer to bargain with the AFL or to assign work to it. The objective which the union sought by the picket line, therefore, was not one prohibited by the express language of Section 8(b)(4)(D). The chances are that the decision will be very narrowly construed and the application of the decision will be restricted to those cases in which it is very obvious that no part of the purpose of the picketing union is to require the employer to assign work to its members.

In only one case has the Board found that the picketing union was justified in picketing to get the work. ${ }^{97}$ In that case the problem was whether

\footnotetext{
94 All of these matters were pointed out to the Second Circuit by the Board on a petition for rehearing in the Local 1250 cases, but it refused to alter its conclusion. Id. at 771. On the question of exclusive bargaining with the majority union, see SEN. REP. No. 573, 74th Cong., 1st Sess. 13 (1935) ; H. R. REP. No. 1147, 74th Cong., 1st Sess. 20-21 (1935), which make it plain that Congress intended in enacting the Wagner Act exactly what the law said, that there should be exclusive bargaining with the majority union. In addition, the Second Circuit evidently ignores what must have been Congress' intention in enacting Section 8(b) (4) (C). Congress intended that there not be dual bargaining and in enacting Section 8 (b) (4) (C) forbade action by a union to coerce dual bargaining.

Q5̆ 29 CODE FED. REG. § 102.77 (1949).

96 Ship Scaling Contractors Assn., 87 N.L.R.B. 92 (1949).

97 Winslow Brothers \& Smith Co., 90 N.L.R.B. 1379 (1950).
} 
a particular job belonged in the production and maintenance unit or in a craft unit of truck drivers. The Board decided that the job belonged in the production unit represented by the picketing union. With the exception of this case the Board has not tried to determine whether history, custom or practice supported the picketing union's claim to the work.

In several cases the Board has noted that the picketing union had no contractual claim to the work, thus inferring that a contract could be a defense..$^{98}$ No Board decision has found picketing justified on the basis of a contract. As a contract requiring that union nembers should be employed to do the work would be a preferential hiring contract and therefore unlawful, it is difficult to perceive what sort of a contract could be a defense. Perhaps a contract would be valid if it provided that present employees of an enployer represented by a particular union should do certain work. The agreement to be valid could not require the employer to hire union members, but it could provide that employees represented by the union when hired should do the work.

The Board has also noted in several decisions that the picketing union had no status as the representatives of the employees doing the work. This would almost inevitably be true as the union normally would not picket if it represented the employees doing the work.

Although Section 8(b) (4) (D) is generally applied to disputes between two unions, it has been invoked when the only union involved picketed to secure assignnient of work being done by non-union employees of the picketed employer. ${ }^{99}$

\section{STRIKES AS VIOLATION OF OTHER SECTIONS OF TAFT-HARTLEY ACT}

A strike or a threat to strike may be unlawful if to force a violation of one of the other sections of Section 8(b); for example, a strike to force an employer to execute an unlawful contract which would discriminate against the employees in violation of Section $8(b)(2)$ is itself a violation of Section 8 (b) (2) and may be restrained. In National Maritime Union v. NLRB the NMU struck for the purpose of securing an unlawful union preference clause in its contract. The Board found the strike to be for the purpose of forcing the employer to violate Section 8 (a)(3) and, therefore, the strike was in violation of Section 8 (b) (2). The Board's order expressly required that the union cease and desist striking or threatening to strike or engaging in any activity in support of a strike for such a purpose. The Circuit Court of Appeals for the Second Circuit enforced the Board's order and the Supreme Court demied certiorari. ${ }^{100}$

It is significant that in this case the Board found that the strike for an unlawful purpose was not necessarily also a violation of Section $8(\mathrm{~b})(1)$ (A) of the Act forbidding coercion and restraint of employees in the exer-

98 W. R. Chamberlin \& Co., 94 N.L.R.B. No. 67 (1951).

99 New London Mills, 91 N.L.R.B. 1003 (1950) ; Direct Transit Lines, 92 N.L.R.B. 1715 (1950).

100 National Labor Rel. Bd. v. National Maritime Union, 175 F.2d 686 (2d Cir. 1949), enforcing 78 N.L.R.B. 971 (1948); cert. denied, 338 U.S. 955 (1950). 
cise of their rights guaranteed by Section 7. In doing so, however, the Board warned that its decision could not be construed as implying that the concerted activity was protected activity or that if the strikers were fired because of their unlawful strike that they would be entitled to reinstatement and back pay if they brought charges. Although the Board does not say so expressly, it is difficult to reach any other conclusion except that a strike in violation of Section 8(b) (2) is necessarily not protected concerted activity and for that reason if employees are fired for engaging in such activity there has been no violation by the employer of the Taft-Hartley Act.

In the American Newspaper Publishers Assn. case, the Board held that the union violated Section 8(b) (1) (B) of the Act (forbidding restraint or coercion of employers in their selection of their representatives) by insisting, through threat of strike, that the employer hire union foremen. ${ }^{101}$ The Board, however, expressly noted that it was not passing on the question of whether a strike for the purpose of forcing an employer to remove specific supervisory employees would necessarily be a violation of Section 8(b) (1) (B), inasmuch as in the $A N P A$ case the union sought to obtain general control of the selection of supervisory employees.

In the Cory Corporation case, the Board held that mass picketing which had the effect of obstructing access to the plant and preventing entrance by employees who desired to enter, was a violation of Section 8(b)(1) (A) forbidding the restraint and coercion of employees in the exercise of their rights guaranteed by Section $7 .^{102}$ Inasmuch as that section guarantees to employees the right not to engage in concerted activities, the mass picket lime restrained or coerced them in their right to refuse to support the strike. The Board did not pass on the question of whether peaceful mass picketing would be a violation as it appeared in the Cory case that the picketing was physically obstructive in character and was not a mere publicizing of the facts of the dispute.

In the $A N P A$ case, the Board, interpreting the $N M U$ case, held that the prohibitions of Section 8(b) (1) (A) "were limited to situations involvmg actual or threatened economic reprisals and physical violence by unions or their agents against specific individuals or groups of individuals in an effort to compel them to join a union or to cooperate in a union's strike activities." 103 This raises a question of whether an organizational picket lime, that is, a picket lime set up for the purposes of coercing employees to join a union by bringing economic pressure upon the employer through the picket line is a violation of the Taft-Hartley Act. ${ }^{104}$ The Board's decisions inake it plain that where the objective is not expressly forbidden, it is not the purpose of picketing but the method or means used in trying to accomplish the purposes which is the important consideration. If the means are unlawful, such as the mass picketing in the Cory case, there has been a vio-

10186 N.L.R.B. 951 (1949).

10284 N.I.R.B. 972 (1949).

${ }^{103}$ Sttpra note 101 at 956.

104 See Lauritzen and Tobriner, The Organizational Picket Line, 3 STAN. I. REv. 413, 423 (1951); Petro, Recognition of Picketing Under the N.L.R.A., 2 CCH LAB. LAw J. 803 (1951). 
lation. If, however, there is merely a peaceful picket and perhaps the placing of the employer on the unfair list (with the result that suppliers and deliverymen observe the picket line and refuse to deliver supplies or carry away products, therefore putting pressure on the employer for the purpose of having him put pressure on the employees), there has been no violation of Section $8(\mathrm{~b})(1)(\mathrm{A})$. It could well be argued that under such circumstances the picketing is part of an unlawful coercive course of conduct having as its object to force the employer to discriminate against the employees in violation of Section 8(a) (3) by either compelling them to join the union or to leave his employ, and the union's activity, therefore, could be in violation of Section 8(b) (2).

Probably Congress did not intend to go this far, particularly as in Section 8(b) (1) (A) it forbids only "restraint or coercion" by unions, as contrasted with Section 8(a)(1) forbidding "interference, restraint or coercion" by employers. Picketing under such circumstances, although it has some elements of coercion, is at the same time an appeal to the employees to align themselves with the union. In some such cases, it may well be that only the employer's resistance to organization is responsible for the employees' failure to affiliate with the union. The picketing, if it results in the breakdown of the employer's resistance, would permit the employees to affiliate voluntarily with the umion. In other cases, it may be that the employees despite their employer's neutrality, see no benefit in union organization and, therefore, are unwilling to join. Anyone who has had a number of years' experience in labor relations recognizes that this is not the normal situation. For that reason the Board's conclusion that such conduct normally is not coercive seems to be in accordance with the realities of industrial life.

A discussion of the right to strike under the Taft-Hartley Act would be incomplete without mention of three other provisions of that law.

\section{UNION MUST BARGAIN BEFORE STRIKING}

Under Section 8(b) (3) it is an unfair labor practice for a union which represents a majority to refuse to bargain collectively with an employer. The duty to bargain collectively is defined in Section 8(d) and contains specific requirements which add up generally to a duty to bargain in good faith with an employer and try to reach agreement on a contract. In addition, a union which has a contract with an employer is required to take the following steps before calling a strike:

(1) Give a 60-day notice of termination to the employer.

(2) Offer to meet and confer regarding a new contract.

(3) Give a 30-day notice to the Federal Mediation and Conciliation Service.

(4) Give a similar 30-day notice to any State Labor Agency.

(5) For a period of 60 days or until the expiration of the contract, if that is niore than 60 days after the notice, the union must continue the existing contract and may not strike during this cooling off period.

If a strike is called during the 60-day cooling off period, the union is 
guilty of an unfair labor practice, and, in addition, any striking employee loses his status as an employee and loses his rights under the law. The employer may reemploy him and he then regains his status as an employee, but the employer is not required to rehire him.

In Wilson and Company, the Labor Board split three ways in interpreting the requirements of this section. ${ }^{105}$ All agreed, however, that the union did not violate the law when it struck after a 60 -day notice given during the existence of a contract which still had a year to run but which contained a wage reopening clause. The majority held that as the contract did not contain a "no strike" clause, a strike could be called during the period of the contract and before its expiration so long as the 60-day cooling off period was observed.

In another case, the Board held that the 60-day notice was to be computed by including the day upon which the employer received the 60-day notice rather than beginning the computation the day after the notice was received. The case was a hard one as, if the 60-day notice was not observed, the employer was justified in his refusal to bargain with the union because the employees would have lost their employee status by striking during the 60-day period. That was the conclusion of the trial examiner, and the case was remanded by the Board for further consideration upon its finding that the union had not struck durmg the 60-day period. The case illustrates the serious consequences of a strike during the 60-day cooling off period. ${ }^{106}$

\section{NATIONAL SECURITY STRIKES}

Under Section 208, strikes which may imperil the national health or safety may be enjoined for a period of approximately 80 days. The President must first find that the national health or safety are imperiled and he may then direct the Attorney General to seek an injunction. The strike or threatened strike must affect an entire industry or a substantial part thereof, must involve interstate commerce, and, of course, nust be sufficiently harmful to the economy to permit a finding that the national health or safety may be imperiled.

Where such a strike exists or is threatened, the President appoints a Board of Inquiry which inquires into the issues involved and makes a written report to the President. This report contains only a summary of the facts of the dispute and the position of the parties and makes no recommendations. The report is then filed with the Conciliation Service and its contents are made public, and at the same time the President may direct the Attorney General to seek an mjunction.

After issuance of the injunction, the President is required to reconvene the Board of Inquiry and at the end of 60 days the Board must give the President a further report, stating the position of the parties, the efforts made for settlement and the einployer's last offer. The law requires the parties in the meantime to confer with the Mediation and Conciliation Service but neither party is required to accept any proposals for settlement.

10589 N.L.R.B. 310 (1950).

106 Ohio Oil Company, 91 N.L.R.B. 759 (1950). 
Within the next fifteen days, the NLRB must take a secret ballot of the employees on the question of whether they wish to accept the employer's final offer and five days after the balloting, the Board is required to certify the results to the Attorney General. The Attorney General then must move to discharge the injunction after certification of the results; or, upon settlement of the dispute, if the dispute is settled before that time.

The Court is required to grant the Attorney General's motion for discharge of the injunction. After the injunction has been vacated, then the President is required to submit a report to the Congress together with any recoinmendations he may see fit to make.

These provisions result in the postponement of a strike for a period of at least eighty days, but after the eighty days have expired there is nothing in the law to compel further efforts to settle the dispute without a strike. It is rather anomalous also that the vote of the employees upon the employer's last offer is completely meaningless. The employees are not required to vote, may boycott the polls if they see fit, and if 100 per cent of the employees who do vote, vote to accept the employer's last offer, there is nothing to compel the union to do so. The procedure appears to rely almost entirely upon the hope that the parties during the injunctive period will settle their dispute, or that if they do not do so the force of public opinion will be sufficient to bring about a settlement.

\section{STRIKES BY GOVERNMENT EMPLOYEES}

Finally, under Section 305, a strike by an employee of the United States or of any agency thereof, including any wholly owned government corporation, is made unlawful and any such employee who strikes must be discharged immediately, forfeits his civil service status, and is ineligible for United States employment for three years.

This section might be invoked not only against Government employees in the strict sense, who have civil service status, but also against employees of Government corporations such as the War Shipping Administration during the last war, the Atomic Energy Commission, or possibly even employees working in Government owned plants. About all that would be required to permit the application of this law would be an agreement between the Government or Government corporation and the private contractor operating the plant, specifying that the employees are to be considered as employees of the United States and not of the contractor.

\section{PENALTY FOR UNLAWFUL STRIKES}

During the foregoing discussion the penalty provided for unlawful strikes has been discussed incidentally in connection with the question of what strikes are unlawful. For unlawful strike activity by employees, or for strikes made unlawful under the Taft-Hartley Act, the employee may suffer the loss of his job. He inay be discharged from his employment without any right of recourse to the National Labor Relations Board for reinstatement or for back pay.

For strikes unlawful under Section 8(b) (4) (A), (B) and (C), the Na- 
tional Labor Relations Board under Section 10(1) must seek an injunction to be effective during the period of consideration by the Board. For strikes unlawful under Section 8(b)(4)(D), the Board may, but is not required to seek such an injunction.

It is notable that the law permits the Board to seek an injunction of a lawful strike because decision by the Board on the lawfulness of the union's conduct occurs after request has been inade for the injunction. There are cases where the Board has found the strike activity to be lawful where a court injunction was sought and secured.

The courts are not required to grant an injunction and some courts have refused to do so although the tendency is to grant an injunction when requested. The discretion lodged in the court has resulted also in a refusal by a court to grant an injunction of an unlawful strike; that is, the court has refused the injunction and subsequently the Labor Board has found the strike to have been unlawful.

If a strike is unlawful under Section 8(b) (4), the injured party may seek damages in a district court action under Section 303 of the TaftHartley Act. ${ }^{107}$ Comparatively few such cases have been filed and fewer have been decided despite the large number of $8(\mathrm{~b})(4)$ charges filed with the Board. For a strike in violation of a contract, damages may be sought under Section 301. This remedy also is seldom used.

In any NLRB unfair labor practice case, the finding by the Board of a violation of the law results in a cease and desist order which may be enforced by a circuit court of appeals decree having the effect of both a mandatory and a prohibitory injunction, as the normal Board order contains both negative and affirmative provisions.

In addition, the Board is permitted by Section $10(j)$ to seek an injunction of any unfair labor practice by either an employer or a union at any time after a complaint has been issued. This power has seldom been used but is available whenever the Government sees fit to use it.

The above summary should be adequate to establish that the TaftHartley Act limits and regulates extensively and constitutionally the ability of a union to exert economic pressure. The remedies for violation are sufficiently drastic to compel obedience to the requirements of the law.

\section{CONCLUSION}

An employer desires to operate his plant at a profit and large damage verdicts, injunctions, the discharge of strikmg eniployees, and similar action, is of little practical value in accomplishimg this main objective. The threat of these consequences is of more value than the fulfilment of the threat. The fear of these results brings pressure to bear on employee representatives for the settlement of their strikes and then after the strike is settled, the employer is interested in efficient production which comes with amicable relations with his employees rather than the inefficiency which would be the product of punitive action. The normally lengthy process of 
an NLRB decision encourages employers not to enforce their rights under the law to the fullest extent. Even if they do, during the time that the Labor Board considers the matter there is always a chance for an amicable settlement of the controversy.

In the final analysis, however, a full and vigorous enforcement of the Taft-Hartley law agamst labor organizations could severely limit and punish the exercise of the right to strike.

Economic pressure solves no labor relations problems; but the ability of a union to exert economic pressure is essential in order to permit it to secure a good contract for its members. A balance of the economic power of employers and enployees is necessary to the proper functioning of our economic system. Unions feared that the Taft-Hartley Act would severely limit legitimate union economic pressure and destroy a proper balance between employers and employee representatives. This fear has not been borne out by experience under the law so far.

The Taft-Hartley Act places powerful weapons in the hands of employers, as well as in the hands of the Government. If unemployment brings a surplus of labor and compels conrpetition for jobs among large numbers of applicants, many employers will be sorely tenpted to use the TaftHartley arsenal to weaken or destroy the unions of their enployees. 